\title{
Climate-induced migration: Will tribunals save the day?
}

\section{Avidan Kent and Simon Behrman}

\section{Introduction}

Much has been said about the link between climate change and migration. ${ }^{1}$ While the exact numbers are disputed, ${ }^{2}$ there seems to be a wide consensus that climate change is affecting the process of human mobility, whether as a major 'push-factor' or as a significant contributing element. ${ }^{3}$ It is also clear that the scale of this phenomenon will be significant - millions will be relocated, in one way or another. ${ }^{4}$

International law will have to provide answers to this emerging phenomenon. To date, the relevant international regulatory framework is patchy and certain gaps seem to exist. ${ }^{5}$ Notable gaps include issues such as statehood and finance. ${ }^{6}$ It is also not clear who is responsible for the damage caused to climate refugees (the issue of causality still acts as a significant barrier), and affected communities do not have the right to seek refuge in a different country, nor are they allowed to stay there legally, at least not on the basis simply that the effects of climate change have forced them from their homes. ${ }^{7}$

This short contribution will open with an evaluation of the development of the international law of climate-induced migration. It will explain that despite notable efforts, a regulatory gap still exists. It will then examine a new strategy, one that in recent years has been employed by communities and civil society organisations wishing to force progress in the fight against climate change - the use of litigation. It seems that at least some of this recent wave of litigation is relevant also in the more specific case of climate-induced migration.

1 See inter alia Jane McAdam (ed.) Climate change and displacement: Multidisciplinary perspectives (OUP 2010), Simon Behrman and Avidan Kent (eds) Climate Refugees: Beyond the legal impasse? (Routledge 2018).

2 See more about the difficulty in estimating the numbers in the context of climate-induced migration in Alex Randall, 'Climate refugees: how many are there? How many will there be?' < http://climatemigration.org.uk/climate-refugees-howmany/>.

3 See inter alia Dina Ionesco et al. The Atlas of Environmental Migration (Routledge 2017).

4 According to a World Bank report, by 2050 the number of climate-induced internally displaced persons alone, in only three regions (Sub-Saharan Africa, South Asia and Latin America) will reach 143 million. Kumari Rigaud et al. Groundswell: Preparing for Internal Climate Migration (The World Bank 2018). See other estimates in Dina Ionesco et al (n 3) 16-17.

5 Avidan Kent and Simon Behrman, Facilitating the resettlement and rights of climate refugees (Routledge 2018). 6 See more in Kent \& Behrman (n 5) Chapter 1.

7 Ibid. 
We will evaluate this new phenomenon and ask whether the use of litigation could be the solution to the longstanding stalemate, and whether some answers will, at last, be provided to the plight of climate refugees. ${ }^{8}$

\section{The development of international law in the context of climate-induced migration?}

The international regulation of climate-induced migration is a relatively new development. Until 2010, the international community was by and large silent on this matter. While climate change was very much at the heart of public debate, the fact that it could lead to mass migration was left untouched - an elephant in the room, whose social and economic implications were almost too big to fathom. In that year, the member states of the United Nations Framework Convention on Climate Change (UNFCCC) admitted, for the first time, that a problem exists. In the, now iconic, Paragraph 14(f) of COP Decision 1/CP.16, the international community was called on 'to enhance action on adaptation [...] by undertaking, inter alia[...] [m] easures to enhance understanding, coordination and cooperation with regard to climate change induced displacement, migration and planned relocation, where appropriate, at the national, regional and international levels'.

This unassumingly vague paragraph ignited a process that, 10 years later, has not yet matured into a concrete change in the regulatory framework. Nonetheless there have been important stepping-stones including non-binding declarations such as the New York Declaration for Refugees and Migrants (2016) and the Global Compact for Safe, Orderly and Regular Migration (2018). These are important: they kept the plight of climate refugees at the heart of the political debate, and inspired further action by states and regional frameworks. ${ }^{9}$ At the same time, it is important to recognise these declarations for what they are - mere political statements that mostly reconfirmed what many have regarded as obvious: climate change is affecting human mobility, and those displaced by climate-related events will require protection. In normative terms, they simply do not add much to the debate.

Other important developments from the previous decade include the adoption of the Nansen Protection Agenda (2015) and the establishment of a UNFCCC-led Taskforce on Displacement (2015). These two steps may provide real utility in the future: the Nansen Protection Agenda

\footnotetext{
8 The reader should be aware that our use of the term 'climate refugee' is controversial. We explain it at great length in Kent \& Behrman (n 5), chapter 2.

9 See for example Beatriz Felipe Perez, 'Climate migration and its inclusion in Mexican legal and political frameworks' in Simon Behrman and Avidan Kent (eds) Climate refugees: global, local and critical approaches (CUP forthcoming).
} 
presents states with useful guidelines and principles on the regulation of climate-induced migration, including criteria for the term 'cross-border disaster-displaced persons'; ${ }^{10}$ useful practices with respect to individuals' admission and stay in host states $;{ }^{11}$ practices concerning the protection of human rights (including on non-return/non-refoulement), and for cases in which long-term stays are required. ${ }^{12}$ The Nansen Initiative has also contributed in terms of global governance: it led to the establishment of the Platform on Disaster Displacement (PDD), an international institution that positioned itself at the forefront of the international efforts to address climate-induced migration.

The UNFCCC-led Taskforce is a cross-institutional body with representatives from a variety of key IGOs. ${ }^{13}$ The Taskforce's objective is 'to develop recommendations for integrated approaches to avert, minimise and address displacement related to the adverse impacts of climate change. ${ }^{14}$ In line with its mandate, in 2018 the Taskforce issued a report with useful recommendations for the UNFCCC and for its member states. ${ }^{15}$ It addressed issues such as governance structure (notably with respect to inclusivity ${ }^{16}$ and coherence/coordination within the UNFCCC, and with other institutions ${ }^{17}$ ), preparedness (e.g. risk assessment and datacollection), ${ }^{18}$ the streaming of migration into other related policies, ${ }^{19}$ and, importantly, finance.

Other less central developments have supplemented these efforts and contributed to this trend. It is important to mention in this respect the adoption of non-binding instruments, such as the Sendai Framework for Disaster Risk Reduction; the Migrants in Countries in Crisis (MICIC) Guidelines; the International Law Commission (ILC) Draft Articles on the Protection of Persons in the Events of Disasters (as well as the ILC mandate to examine issues of sea-level

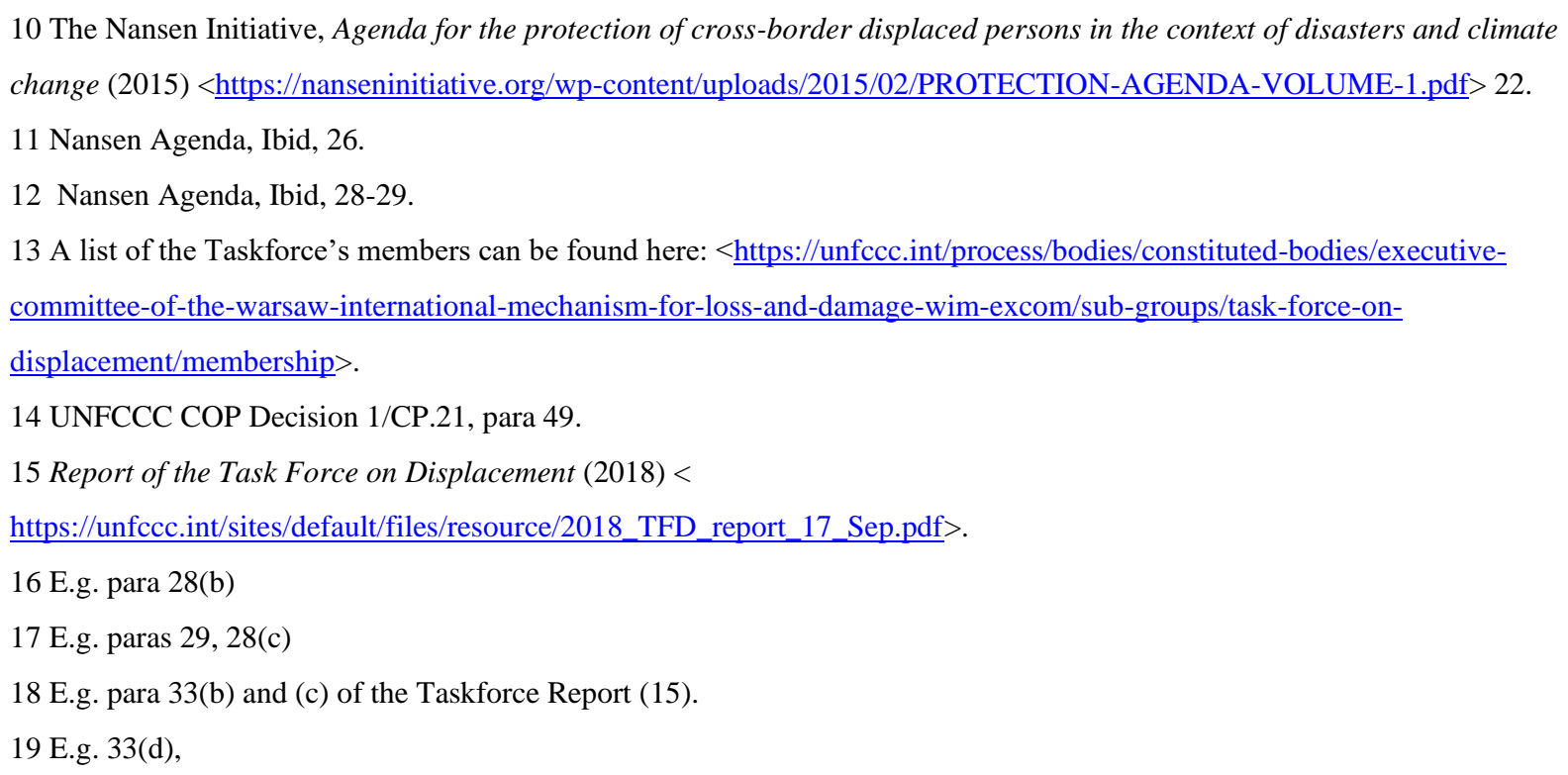


rise in relation to international law); the Global Compact on Refugees, and to a lesser extent statements by bodies such as the International Law Association (ILA) and UN treaty committees. $^{20}$

These developments have all been useful: they provided valuable blueprints and guidelines as to the shape of future negotiations and regulation. To date, however, they have not brought us any closer to a significant change in the regulatory framework, and the gaps identified in the literature remain as they were. The main legal frameworks that are relevant to the phenomenon - notably the UNFCCC and the 1951 Refugee Convention - have not been adjusted in any significant way in order to address the plight of climate refugees. None of the many models proposed by authors in the literature have been adopted, ${ }^{21}$ and longstanding legal hurdles - for example with respect to liability - have not been addressed, allowing states to continue and hide behind excuses such as the lack of direct causality. ${ }^{22}$

In short, it is clear that the international community has been busy in the last decade or so. From the perspective of climate refugees, however, it is questionable whether much has changed: their legal rights, and states' liabilities towards them, remained unchanged.

\section{Courts to the rescue?}

The problem of climate-induced migration sits within a much larger international political standstill - the international efforts to reduce global emissions and address climate change. The international community has been trying for decades to reach a binding agreement that will instruct states to reduce their emission to a level that will be regarded as safe. ${ }^{23}$ The highlight

\footnotetext{
20 See for example the ILA Sydney Declaration of Principles on the Protection of Persons Displaces in the Context of Sea Level Rise (2018) <https://environmentalmigration.iom.int/sydney-declaration-principles-protection-persons-displacedcontext-sea-level-rise\%C2\%A0>, and the Joint Statement on "Human Rights and Climate Change" < https://www.ohchr.org/en/NewsEvents/Pages/DisplayNews.aspx?NewsID=24998\&LangID=E>.

21 See review of different proposals in Kent \& Behrman (n 5) chapter 1.

22 States are avoiding responsibility vis-à-vis the damage caused to climate refugees (and their home/host states) by pointing to the double-causality problem: the impossibility of establishing a causal link between the emissions of one specific state and a specific (climate-induced) damage, and the difficulty in establishing a causal link between climatic changes and the decision to migrate, which in many cases involves multiple push factors.

23 The Paris Agreement defines this level as 'well below $2{ }^{\circ} \mathrm{C}$ above pre-industrial levels and pursuing efforts to limit the temperature increase to $1.5^{\circ} \mathrm{C}$ above pre-industrial levels'.
} 
of this effort - the Paris Agreement - is regarded by many as unsatisfactory due to its soft mechanisms and lack of ambition.

The result of this political impasse has been widespread disillusionment, followed by a search for new and more effective strategies that will lead to better results. Notably, many groups have turned to national and international courts, ${ }^{24}$ hoping that whatever states were unable to agree on in political negotiations will be delivered through judicial evolution (or even activism). These groups have asked for a variety of remedies, ranging from greenhouse emissions reductions to compensation, protection of human rights affected by climate change, and declaratory statements.

Most of these attempts were unsuccessful. Courts are reluctant to 'develop' the law on matters that are still subject to sensitive political negotiations. Perhaps the most cited (and explicit) rejection on these grounds was made in the US Juliana case. While sympathetic to the claimants' demand to phase-out greenhouse emissions, the US Court of Appeal of the Ninth Circuit has 'reluctantly concluded that the plaintiffs' case must be made to the political branches or to the electorate at large. ${ }^{25}$ A similar position was taken by other courts, rejecting claims on similar grounds, ${ }^{26}$ as well as others. ${ }^{27}$

A few success stories nevertheless exist. Some courts have agreed to adjudicate climate cases despite their clear political implications, ${ }^{28}$ and on rare occasions even to issues operative decisions against the state. A rare, notable example, is the Dutch Supreme Court's ruling in the

24 See for example Joana Setzer and Rebecca Byrnes, 'Global trends in climate change litigation: 2019 snapshot' Policy report July 2019 <http://www.lse.ac.uk/GranthamInstitute/wp-content/uploads/2019/07/GRI_Global-trends-in-climatechange-litigation-2019-snapshot-2.pdf>; Annalisa Savaresi and Juan Auz 'Climate Change Litigation and Human Rights: Pushing the Boundaries' (2019) 9(3) Climate Law 244.

25 Juliana et al vs the United States of America Case: 18-36082, (01/17/2020), 5.

26 Plan B Earth vs Secretary of State for Business, Energy and Industrial Strategy Case No: CO/16/2018 (20 July 2018), para 49; Greenpeace vs Government of Norway $<$ https://climate-

laws.org/cclow/geographies/norway/litigation_cases/greenpeace-norway-v-government-of-norway>; Friends of the Irish Environment vs Ireland https://climate-<laws.org/cclow/geographies/ireland/litigation_cases/friends-of-the-irish-

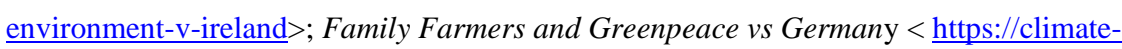
laws.org/cclow/geographies/germany/litigation_cases/family-farmers-and-greenpeace-germany-v-germany >.

27 For example the lack of legal standing (Armando Ferrão Carvalho and others vs The European Parliament and Council (n 40).

28 See for example Environnement Jeunesse vs Attorney General of Canada $<$ https://climate-

laws.org/cclow/geographies/canada/litigation_cases/environnement-jeunesse-v-canada> 
the Urgenda case (2019), ${ }^{29}$ in which the state was ordered to reduce its emission levels. Another important decision was made by the Human Rights Committee in the Teitiota case (2020), which confirmed that the impact of climate change on islanders' right to life could be significant enough to justify protection, and effectively prohibit their deportation to sinking islands. ${ }^{30}$ Other 'rays of hope' could be found in fierce dissenting opinions, such that provided by Judge Staton in the Juliana case, who condemned the majority's decision to leave this decision to the political branch:

'The majority laments that it cannot step into the shoes of the political branches, [...], but appears ready to yield even if those branches walk the Nation over a cliff., ${ }^{31}$

With a substantial number of cases still pending at the time of writing, ${ }^{32}$ it could be that the more activist approach will find more support, at least in some courts.

\section{Litigating climate-induced migration?}

What can this barrage of cases mean for the more specific legal gap, in the context of climateinduced migration? To begin with, many of the requested remedies are relevant to the case of climate-induced migration. For example, requests for emissions cuts will, if successful, mitigate the push-factors that are leading to climate-induced migration. Remedies that are addressing human rights violations are also of direct importance for climate-refugees, whose protection was signalled on many occasions as a key objective. Even more specifically, in some cases communities have asked for financial remedies in the shape of adaptation funds, which will allow communities to address climate change and avoid displacement. ${ }^{33}$ In one very highprofile case, the claimant asked for a remedy that will de facto prevent his deportation to his sinking island nation. ${ }^{34}$

\footnotetext{
29 Urgenda vs Netherlands (Netherlands' Supreme Court, 20/12/2019)

30 Ioane Teitiota v. New Zealand (advance unedited version), CCPR/C/127/D/2928/2016, UN Human Committee (HRC), 7 January 2020.

31 Juliana (n 25) 49.

32 See a list of climate-related cases here $<$ https://climate-laws.org/cclow/litigation cases $>$.

33 E.g. Petition to the Inter American Commission on Human Rights seeking relief from violations resulting from global warming caused by acts and omissions of The United States (2005); Petition of Torres Strait Islanders to the United Nations Human Rights Committee Alleging Violations Stemming from Australia's Inaction on Climate Change.

34 Ioane Teitiota v. New Zealand (n 30).
} 
It is therefore not surprising to find that the issue of climate-induced migration was explicitly mentioned in many of these petitions/claims, including those submitted in the national courts of Peru, ${ }^{35}$ Canada, ${ }^{36}$ Pakistan, ${ }^{37}$ India ${ }^{38}$ and the United States. ${ }^{39}$ On the international level, climate-induced migration was mentioned in petitions submitted to the European Court of Justice, ${ }^{40}$ the Inter-American Commission on Human Rights, ${ }^{41}$ the UN Human Rights Committee (HRC), ${ }^{42}$ and the United Nations Committee on the Rights of the Child. ${ }^{43}$

As many of these cases are still pending, it is difficult to know how (and if) their resolution will develop the law on climate-induced migration. Early indications, however, suggest that they will, even if only in a limited way. Importantly, the HRC's Teitiota case was described by many as a 'landmark', 'a ground-breaking asylum case' ${ }^{44}$ and a decision that 'opens [the] door to climate change asylum cases' ${ }^{45}$ There is no doubt that this decision indeed developed the law in an important manner: it confirmed that in extreme cases, the impact of climate change

35 Álvarez et al v. Peru (complaint, 2019) <https://climate-laws.org/cclow/geographies/peru/litigation_cases/alvarez-et-al-vperu> 101.

36 La Rose v. Her Majesty the Queen (complaint, 2019) < https://climate-

laws.org/cclow/geographies/canada/litigation_cases/la-rose-v-her-majesty-the-queen $>75-77,232$ (e).

37 Ali v. Federation of Pakistan (petition, 2016) < https://climate-laws.org/cclow/geographies/pakistan/litigation cases/ali-vfederation-of-pakistan-supreme-court-of-pakistan-2016> para 16, 26, xxviii.

38 Pandey vs India (petition) 〈https://climate-laws.org/cclow/geographies/india/litigation_cases/pandey-v-india > p. 29

39 Juliana et al vs the United States of America (First Amended Complaint for Declaratory and Injunctive Relief) Case paras 66,70 , and to a certain extent 239-240.

40 Armando Ferrão Carvalho and others vs The European Parliament and Council (application, 2018), paras 78-82, 410(h).

41 Request for a hearing on the impacts of climate change on human rights $(2019)<\underline{\text { https://climate- }}$

laws.org/cclow/geographies/international/litigation_cases/hearing-on-climate-change-before-the-inter-americancommission-on-human-rights> 9; Petition to the Inter American Commission on Human Rights (n 33).

42 Ioane Teitiota v. New Zealand (n 30); Petition of Torres Strait Islanders to the United Nations Human Rights Committee (n 33).

43 Communication to the Committee on the Rights of the Child, in the Case of Chiara Sacchi et al (2019)

https://childrenvsclimatecrisis.org/wp-content/uploads/2019/09/2019.09.23-CRC-communication-Sacchi-et-al-v.-Argentinaet-al.pdf 2. 6. 21. 43 .

44 Amnesty International, 'UN landmark case for people displaced by climate change' < https://www.amnesty.org/en/latest/news/2020/01/un-landmark-case-for-people-displaced-by-climate-change/>.

45 UHCHR, 'Historic UN Human Rights case opens door to climate change asylum claims' <

https://www.ohchr.org/EN/NewsEvents/Pages/DisplayNews.aspx?NewsID=25482\&LangID=E>. 
could impose a significant threat to one's right to life. ${ }^{46}$ This confirmation is important, as it creates the possibility that climate refugees will enjoy the protection provided by the nonrefoulement rule, effectively prohibiting their deportation to their home countries. On the face of it, this is an important development that addresses what is perhaps the most significant gap in the international regulatory framework: the right to enter another state and remain there legally. As we discuss elsewhere ${ }^{47}$ certain limitations on this possibility nevertheless exist. Notably, claimants will need to overcome barriers, including establishing that the risk is personal in nature ${ }^{48}$ (which is rarely the case with climate change) and that the risk is imminent (which will be difficult to establish in slow-onset climate-related events). These limitations, we believe, water-down the importance of this decision.

Another important development of the law is related to causality. The double-problem of causality forms a barrier for any claim regarding states' liability in the context of climateinduced migration. First, it is difficult to establish a direct link between specific emissions polluted in/by any given state and the environmental damage that pushed a certain individual to leave their home. This difficulty forms an easy way out for any country wishing to evade responsibility. ${ }^{49}$ Secondly, it can also be difficult to isolate climate change as the sole/leading reason that led to one's migration. Often enough, the decision to migrate is made due to a combination of push-factors, rather than just due to climate change.

The second causal link is not insurmountable, ${ }^{50}$ especially in cases that involve a rise in sealevels (e.g. disappearing island nations). In these cases, climate change could be easily identified as a major (if not the only) reason for migration. Other economic and social difficulties often arise out of environmental damage, and cannot be distinguished from it.

46 The right to life in this case was based on Article 6 of the 1966 International Covenant on Civil and Political Rights (ICCPR), UN General Assembly, International Covenant on Civil and Political Rights, 16 December 1966, United Nations, Treaty Series, vol. 999, p. 171.

47 Simon Behrman and Avidan Kent, 'Prospects for protection in light of the Human Rights Committee's decision in Teitiota v New Zealand', Polish Migration Review (forthcoming).

48 It should be noted that the HRC confirmed that in extreme cases, claims can be made based on general conditions, rather than purely personal ones, although there is a 'high threshold' in establishing such a claim. See Ioane Teitiota v. New Zealand (n 30), para 9.3.

49 See for example the position of Brazil Germany and France in the Case of Chiara Sacchi et al (n 43) as described in the reply to these countries submissions (the submissions are currently unavailable), <http://blogs2.law.columbia.edu/climatechange-litigation/wp-content/uploads/sites/16/non-us-case-documents/2020/20200504_Not-available_reply.pdf> para 12. 50 Behrman and Kent (n 47). 
The first causal link is more difficult to address with existing legal tools. Here, the emerging jurisprudence has been useful. We have proposed that the 'no harm' principle can be relied on in this context, and that the causal link can be established in the following manner:

'[W]hile an exact causal link is hard to come by, it is not impossible to find a 'close enough' causal link. We know, for example, the percentage of GHGs emitted by each state; it could be decided that the funding of efforts to deal with the problem of climateinduced migration could be allocated based on these data. ${ }^{51}$

More recently, the Dutch Supreme Court has made a very similar point. They referred to the 'no harm' rule as the source for attributing responsibility:

'Countries can be called to account for the duty arising from this principle. Applied to greenhouse gas emissions, this means that they can be called upon to make their contribution to reducing greenhouse gas emissions. This approach justifies partial responsibility: each country is responsible for its part and can therefore be called to account in that respect. 52

This quantified partial responsibility could be useful in litigation also beyond the context of the Urgenda case, notably as a liability mechanism that will justify compensation. This possibility will naturally concern major polluters, hopefully enough to push them back to the negotiating table, or simply to pledge additional funds, as Australia recently did following a complaint submitted against it to the HRC. ${ }^{53}$

Other courts have addressed this barrier of causality as well. The US Court of Appeal of the Ninth Circuit has rejected in the Juliana case the State's claim regarding the lack of causality, stating that ' $[\mathrm{t}]$ here is at least a genuine factual dispute as to whether those policies were a "substantial factor" in causing the plaintiffs' injuries.' The Court explicitly accepted that the claimants injuries are the result of carbon emissions, and that '[a] significant portion of those emissions occur in this country'. ${ }^{54}$ The Court eventually rejected the claimants' petition before

51 Kent \& Behrman (n 5) 91.

52 Urgenda (n 29) para 5.7.5.

53 'Torres Straight Islanders win key ask after climate complaint' (19 February 2020) ClientEarth < https://www.clientearth.org/torres-strait-islanders-win-key-ask-after-climate-complaint/>.

54 Juliana (n 25) 20. 
making a ruling on this very matter (as discussed above), but it seems clear that it was determined not to allow the causality matter to form a barrier.

\section{Conclusion}

While the international community is reluctant or unable to close the longstanding legal gap, it is possible that the current wave of climate litigation will bring about at least some useful answers. The many pending cases indicate that scholars and states alike should pay closer attention to this space, and, hopefully, await even further developments. The power of courts is not necessarily in their binding decisions; many of the decisions mentioned above are indeed not binding in nature, or at least limited to a unique jurisdiction. These decisions could, however, inspire the understanding of specific issues (e.g. causality) or instruct states on the application of older rules in the context of a new phenomenon - climate-induced migration. The current political stalemate may change in the future and the blocked negotiations may result in new, binding regimes. Until they do, the operation of tribunals is one place where our focus should be. 